\title{
THE QUANTITATIVE CONTENT OF THE MAIN GROUPS OF BIOLOGICALLY ACTIVE SUBSTANCES IN THE BAY LAUREL RAW MATERIAL
}

\author{
S.G.Musienko, V.S.Kyslychenko
}

National University of Pharmacy

Key words: biologically active substances; bay laurel; quantitative content

The study of the chemical composition of the bay laurel raw material has shown that the plant raw material contains such groups of biologically active substances (BAS) as carbohydrates, fatty and amino acids, phenolic compounds revealing a wide spectrum of the biological activity. The data concerning the chemical composition of the bay laurel raw material is not enough described in the literature sources. The content of the main BAS in different samples of bay laurel shoots and leaves has been determined. The content of the total amount of organic acids, the total amount of oxidizable phenols, the total amount of hydroxycinnamic acids and the total amount of flavonoids in the bay laurel leaves samples are slightly higher. The content of the total amount of organic acids in shoots is not less than $1.7 \%$, in leaves - not less than $1.9 \%$. The content of the total amount of oxidizable phenols in both types of the raw material is not less than $4.5 \%$, the total amount of hydroxycinnamic acids - not less than $1.3 \%$, the total amount of flavonoids - not less than $0.8 \%$. The standardization parameters for the bay laurel raw material have been determined on the basis of the research conducted. The results obtained will be used for developing the project of quality control methods "Lauri Cormus".

The profound research of the medicinal plant raw material previously studied for the potential expansion of the aspects of its application is a topical task of modern pharmacy. Our attention was attracted to plants of the Lauraceae family, Laurus L. genus combining 3 species - Laurus azorica (Seub.) Franco, Laurus nobilis L., Laurus porrecta Roxb. (the latter species is related to Cinnamomum genus, Cinnamomum porrectum (Roxb.) Kosterm. species) [3]). The most wide-spread species is bay laurel - an evergreen tree or a shrub up to $10 \mathrm{~m}$ high. Bay laurel fruits were included into 6 pre-revolutionary editions of the Russian Pharmacopoeia, and the State Pharmacopoeia of the USSR, the $1^{\text {st }}$ ed. Its leaves are used in the treatment of throat cancer, psoriasis, arthritis, pain in joints, cramps, diabetes. The bay laurel oil obtained with flax or sunflower oil is used in the cases of paralysis, rheumatism, etc. The essential oil from leaves contains 1,8-cineol, terpinen-4-ol, $\alpha$-pinene, $\beta$-pinene, linalool acetate [15], as well as $\beta$-cymene, $\beta$-longipirene, cadinene, $\alpha$-terpinyl acetate, $\alpha$-balnesene [12]. BAS of bay laurel are considered to reveal wound-healing [14], anti-inflammatory [10], antinociceptive [10], immune stimulating [5], neuroprotective [11, 14], anticholinergic [14], anti-oxidant $[6,8,9,13]$, anti-ulcer, anti-convulsant, antimutagenic [14], insecticidal [4], antibacterial $[7,14]$, antiviral, antifungal [14], larvicidal [15] activities. At the same time bay laurel is contraindicated in the cases of glomerulonephritis, pregnancy, tendency to bleedings, amyloidosis. Moreover, medicines produced from this plant are absent nowadays. Thus, the profound studies of the bay laurel raw material and creation of new substances on its basis are up to date.

The study of the chemical composition of the bay laurel plant raw material has shown that the plant con- tains such groups of BAS as carbohydrates, fatty and amino acids, phenolic compounds. The data concerning the chemical composition of the bay laurel raw material is not enough described in the literature sources. Thus, the aim of our research was to determine the quantitative content of the main BAS groups in the bay laurel raw material.

\section{Materials and Methods}

The objects of the study were the bay laurel shoots and leaves collected in November, 2013 in Alushta (Sample 1) and Rybachye (Crimea) (Sample 2).

The method described in the State Pharmacopoeia of the USSR, the XI-th ed., art. 38 "Rosae fructus" [2] was used to determine the total amount of organic acids calculated with reference to malic acid. The total amount of oxidizable phenols was determined using the method described in the State Pharmacopoeia of the USSR, the XI-th ed. [2].

The quantitative content the total amount of hydroxycinnamic acids in the bay laurel raw material was determined by the spectrophotometric method calculated with reference to chlorogenic acid [1]. For this purpose, place $2.0 \mathrm{~g}$ (accurate weight) of the cut plant raw material passing through the sieves with the size of $1 \mathrm{~mm}$ in diameter into a $200 \mathrm{ml}$ conical flask and add $60 \mathrm{ml}$ of $50 \%$ ethanol. Attach the flask to a reflux condenser and heat on a boiling water bath for $15 \mathrm{~min}$. After cooling filter the content of the flask through a paper filter into a $100 \mathrm{ml}$ conical flask. Repeat the extraction twice under the same conditions.

Transfer the extracts obtained quantitatively into a $200 \mathrm{ml}$ volumetric flask and dilute the solution to the volume with $50 \%$ ethanol (Solution A). Place $1 \mathrm{ml}$ of Solution A into a $50 \mathrm{ml}$ volumetric flask and dilute the solution to the volume with $50 \%$ ethanol. 
Results of the quantitative determination of the main BAS in the bay laurel raw material $(\mathrm{m}=5, \mathrm{P} \geq 0.95, \%$ calculated with reference to the dry raw material)

\begin{tabular}{|c|c|c|c|c|}
\hline \multirow{2}{*}{\begin{tabular}{|c|} 
No. \\
of the sample
\end{tabular}} & \multicolumn{4}{|c|}{ Quantitative content of, $\mathrm{X} \pm \Delta \mathrm{X}$} \\
\hline & organic acids & oxidizable polyphenols & hydroxycinnamic acids & flavonoids \\
\hline \multicolumn{5}{|c|}{ Shoots } \\
\hline 1 & $1.75 \pm 0.01$ & $4.80 \pm 0.12$ & $1.35 \pm 0.08$ & $0.85 \pm 0.03$ \\
\hline 2 & $1.81 \pm 0.01$ & $4.54 \pm 0.17$ & $1.29 \pm 0.07$ & $0.81 \pm 0.07$ \\
\hline \multicolumn{5}{|c|}{ Leaves } \\
\hline 1 & $2.14 \pm 0.09$ & $5.25 \pm 0.16$ & $1.73 \pm 0.05$ & $0.95 \pm 0.06$ \\
\hline 2 & $1.98 \pm 0.02$ & $5.04 \pm 0.11$ & $1.71 \pm 0.05$ & $0.91 \pm 0.05$ \\
\hline
\end{tabular}

The optical density of the solution obtained was measured using a Lomo SF - 46 spectrophotometer at the wavelength of $327 \mathrm{~nm}$. As the reference solution $50 \%$ ethanol was used. The content of the total amount of hydroxycinnamic acids in per cents calculated with reference to chlorogenic acid was calculated using the formula:

$$
\mathrm{X}=\frac{\mathrm{A} \cdot 200 \cdot 50 \cdot 100 \cdot 100}{E_{1 \mathrm{~cm}}^{1 \%} \cdot m \cdot(100-W)},
$$

where: $\mathrm{A}$ - is the optical density of the solution studied; $\mathrm{m}-$ is the raw material weight, $\mathrm{g} ; W-$ is the weight loss on drying, $\% ; \mathrm{E}_{1 \mathrm{~cm}}^{1 \%}$ - is the specific absorption coefficient of chlorogenic acid (531).

The content of the total amount of flavonoid glycosides was determined using the method described in literature [1]. Place $4 \mathrm{ml}$ of Solution A (obtained by the method described above) into a $50 \mathrm{ml}$ volumetric flask, add $4 \mathrm{ml}$ of $3 \%$ ethanol solution of aluminium chloride and dilute the solution to the volume with $50 \%$ ethanol. Place the solution containing $4 \mathrm{ml}$ of Solution A into a $50 \mathrm{ml}$ volumetric flask and dilute the solution to the volume with $50 \%$ ethanol. The solution obtained was used as the reference solution.

Both solutions were filtered through a "blue strip" paper filter discarding the first filtrate portions, and the solutions were analyzed in $30 \mathrm{~min}$ after preparation.

The optical density was determined at the wavelength of $417 \mathrm{~nm}$. The content of the total amount of flavonoids $(X)$ was calculated with reference to rutin using the formula:

$$
x=\frac{A \cdot 2500 \cdot 100 \cdot 100}{\mathrm{E}_{1 c m}^{1 \%} \cdot m \cdot(100-W)},
$$

where: $A$-is the optical density of the solution studied; $\mathrm{E}_{1 \mathrm{~cm}}^{1 \%}$ - is the specific absorption coefficient of rutin (257); $\mathrm{m}-$ is the raw material weight, $\mathrm{g} ; W-$ is the weight loss on drying, $\%$.

\section{Results and Discussion}

The data obtained are generalized in the Table. The content of the total amount of organic acids, of the total amount of oxidizable phenols, of the total amount of hydroxycinnamic acids and of the total amount of flavonoids was found to be slightly higher in samples of the bay laurel leaves than in shoots.
The highest content of the total amount of organic acids was found in leaves of Sample $1(2.14 \pm 0.09 \%)$. The content of this group of BAS in leaves was not less than $1.9 \%$, in shoots - not less than $1.7 \%$.

The content of the total amount of oxidizable phenols was not less than $4.5 \%$ calculated with reference to the absolutely dry plant raw material independently from its type and the place of gathering. The highest content of this group of BAS was determined in the bay laurel leaves (Sample 1) - 5.25 $\pm 0.16 \%$, which was only 1.2 times higher than in shoots of Sample 2 (the lowest value $-4.54 \pm 0.17 \%$ ).

According to the data obtained the content of the total amount of hydroxycinnamic acids in all types of the raw material was not less than $1.3 \%$. The variability of this value was insignificant. The highest content was determined in the bay laurel leaves of Sample 1 $(1.73 \pm 0.05 \%)$. The lowest content of this group of BAS (1.34 times lower than the highest value) was found in shoots of Sample 2 (1.29 $\pm 0.07 \%)$.

The quantitative content of the total amount of flavonoids was not less than $0.8 \%$ in all types of the raw material. The results 1.2 times varied depending on the place of collection and the type of the raw material: from $0.95 \pm 0.06 \%$ (leaves of Sample 1) up to $0.81 \pm 0.07 \%$ (shoots of Sample 2).

\section{CONCLUSIONS}

1. The quantitative content has been determined in 2 samples of the bay laurel shoots and leaves; the lower content values of the main groups of BAS - the total amount of organic acids, as well as different phenolic compounds (the total amount of oxidizable phenols, the total amount of hydroxycinnamic acids and the total amount of flavonoids) have been found. The content of the total amount of organic acids in shoots was not less than $1.7 \%$, in leaves - not less than $1.9 \%$. The content of the total amount of oxidizable phenols in both types of the raw material was not less than $4.5 \%$, the total amount of hydroxycinnamic acids - not less than $1.3 \%$, the total amount of flavonoids - not less than $0.8 \%$.

2 . The standardization parameters for the bay laurel plant raw material have been determined on the basis of the research conducted. The results obtained are necessary for developing the project of quality control methods "Lauri Cormus". 


\section{REFERENCES}

1. Волошина А.А., Кисличенко В.С., Журавель I.О. та ін. // Укр. мед. альманах. - 2012. - T. 15, №5. - С. 39-40.

2. Государственная фармакопея СССР. Вып. 2. Общие методы анализа. Лекарственное растительное сырье / МЗ СССР. - 11-е изд. - М.: Медииина, 1989. - 400 c.

3. Пилипенко Ф.С. / Под ред. С.Я.Соколова. - М. - Л.: Изд-во АН СССР, 1954. - Т. ІІІ. Покрытосеменные. Семейства Троходендроновые - Розоцветные. - С. 122-123.

4. Ben Jemaa J.M., Tersim N., Toudert K.T. et al. // J. Stored Prod. Res. - 2012. - Vol. 48. - P. 97-104.

5. Bilen S., Bulut M. // J. of Animal and Veterinary Advances. - 2010. - Vol. 9 (8). - P. 1275-1277.

6. Dall'Acqua S., Cervellati R., Speroni E. et al. // J. of Medicinal Food. - 2009. - №12. - P. 869-876.

7. Derwich E., Benziane Z., Boukir A. // Aust. J. Basic. Appl. Sci. - 2009. - №3. - P. 3818-3824.

8. Dias M.I., Barros L., Dueñas M. et al. // Food Chemistry. - 2013. - Vol. 141. - P. 869-872.

9. Emam A.M., Mohamed M.A., Diab Y.M. et al. // Drug Discoveries and Therapeutics. - 2010. - Vol. 4 (3). - P. 202-207.

10. Esra K., Ilkay O., Erdem Y. // Pharmac. Biol. - 2007. - Vol. 45, Issue 7. - P. 547-555.

11. Ham A., Shin J., Oh K. et al. // Biomol. Ther - 2011. - Vol. 19, Issue 1. - P. 118-125.

12. Marzouki H., Piras A., Marongiu B. et al. // Molecules. - 2008. - Vol. 13. - P. 1702-1711.

13. Ozcan B., Esen M., Sangun M.K. et al. // J. Environ. Biol. - 2010. - Vol. 31. - P. 637-641.

14. Ramling P., Meera M., Priyanka P. // Int. J. of Pharm. and Chem. Sci. - 2012. - Vol. 1 (2). - P. 595-602.

15. Rizi M.V. // Iranian J. of Pharmac. Sci. - 2009. - Vol. 5, Issue 1. - P. 47-50.

КІЛЬКІСНИЙ ВМІСТ ОСНОВНИХ ГРУП БІОЛОГІЧНО АКТИВНИХ РЕЧОВИН У СИРОВИНІ ЛАВРА БЛАГОРОДНОГО

С.Г.Мусієнко, В.С.Кисличенко

Ключові слова: біологічно активні речовини; лавр благородний; кількісний вміст

Вивчення хімічного складу сировини лавра благородного показало, що сировина рослини містить такі групи БАР, як вуглеводи, кислоти жирні, амінокислоти, фенольні сполуки, що проявляють широкий спектр біологічної дії. В літературних джерелах відомості про хімічний склад сировини лавра благородного не достатньо повні. Визначено вміст основних груп БАР у різних зразках пагонів та листя лавра благородного. Вміст БАР, що досліджувалися, майже не відрізняється в обох видах сировини, що вивчалася. При цьому вміст суми органічних кислот становить у пагонах не менше 1,7\%, в листі - не менше 1,9\%, вміст суми окиснюваних френолів становить для обох видів сировини не менше 4,5\%, суми кислот гідроксикоричних - не менше 1,3\%, суми фрлавоноїдів - не менше 0,8\%. На підставі проведених досліджень визначені показники доброякісності сировини, які будуть використані при розробці відповідних розділів проекту МКЯ «Lauri cormus».

\section{КОЛИЧЕСТВЕННОЕ СОДЕРЖАНИЕ ОСНОВНЫХ ГРУПП БИОЛОГИЧЕСКИ АКТИВНЫХ ВЕЩЕСТВ В СЫРЬЕ ЛАВРА БЛАГОРОДНОГО \\ С.Г.Мусиенко, В.С.Кисличенко}

Ключевые слова: биологически активные вещества; лавр благородный; количественное содержание

Изучение химического состава сырья лавра благородного показало, что сырье содержит такие группы БАВ, как углеводы, жирные кислоты, аминокислоты, френольные вещества, которые проявляют широкий спектр биологической активности. В литературных источниках сведения о химическом составе сырья лавра благородного недостаточно полные. Определено содержание основных групп БАВ в разных образцах побегов и листьев лавра благородного. Содержание суммы органических кислот, суммы окисляемых фенолов, суммы оксикоричных кислот и суммы фрлавоноидов в образцах листьев незначительно выше. При этом содержание суммы органических кислот составляет в побегах не меньще 1,7\%, в листьях - не меньше 1,9\%, содержание суммы окисляемых фенолов составило для обоих видов сырья не меньше 4,5\%, суммы оксикоричных кислот - не меньше 1,3\%, суммы фрлавоноидов - не меньше 0,8\%. На основании проведенных исследований определены показатели доброкачественности сырья, которые будут использованы при разработке соответствующих разделов проекта MKK «Lauri cormus». 